\title{
Quantificação e otimização de DNA em diferentes composições de Sisal (Agave sisalana Perrine)
}

\author{
Pedro Alcantara da Silva Abreu ${ }^{1}$; Adriana Rodrigues Passos ${ }^{2}$; Rogério Mercês Ferreira \\ Santos $^{3}$; Janáira Lopes do Santos Carneiro ${ }^{4}$ \\ 1. Mestrando em Agronomia: Irrigação e Drenagem, Universidade Estadual Paulista "Júlio de Mesquita", e-mail: \\ pedro_804@outlook.com \\ 2. Professora Adjunta, Orientadora, Departamento de Ciências Biológicas, Universidade Estadual de Feira de Santana e-mail: \\ adrianarpassos@yahoo.com.br \\ 3. Professor Substituto, Departamento de Ciências Biológicas, Universidade Estadual de Feira de Santana e-mail: \\ rogeriomerces@gmail.com \\ 4. Doutora em Recurso Genético Vegetal, Co-orientadora, Universidade Estadual de Feira de Santana, e-mail: \\ janairacarneiro@hotmail.com
}

PALAVRAS-CHAVE: Agave Sisalana Perr.; Melhoramento Genético; Biotecnologia

\section{INTRODUÇÃO}

A Agave Sisalana Perr. (Sisal) pertence à família Agavaceae, e tem como principal produto de interesse comercial suas fibras resistentes extraídas das folhas. O Brasil se destaca na agaveicultura como o maior produtor e exportador mundial da fibra. Segundo a FAO, no ano de 2009, a produção brasileira correspondeu a cerca de 50\% da produção mundial (Aquino, 2011).

A diversidade genética compreende várias frequências alélicas presentes em um mesmo grupo de indivíduos, que em conjunto com o ambiente irão fornecer a natureza do fenótipo, que servirá de base para programas de melhoramento genético (Cardona, 2010). O estudo da diversidade genética, através do uso de marcadores moleculares, possibilita a formação de estratégias para conservação de recursos genéticos, economizando tempo e custo para o estudo de genética de populações (Santos et al., 2007; Ferreira, 2003)

No entanto, estudos moleculares dependem diretamente da qualidade do DNA extraído, desse modo a otimização e estabelecimento de protocolos de extração são necessários, visto que um bom procedimento de extração deve produzir DNA de pureza, qualidade e quantidades adequadas para manipulação (Romano, 1998). Ademais, as técnicas de quantificação fornecem informações importantes, destacando a confirmação da pureza da amostra de DNA, ou seja, DNA livre de proteínas, RNA, dentre outras impurezas, visto que um dos objetivos da extração é fornecer DNA de boa qualidade (Tiwari, 2012). A exatidão na quantificação da amostra é também requisito essencial para as técnicas posteriores à extração, onde se determina o perfil genético (Butler, 2010).

A quantificação do conteúdo de DNA tem sido reconhecida como um relevante parâmetro para a caracterização genômica, com aplicação nos estudos evolutivos, além de fornecer informações úteis para o planejamento de projetos de sequenciamento e em trabalhos envolvendo marcadores moleculares (Bennett; Leitch, 2005). Em razão disso, este trabalho tem por objetivo quantificar o DNA de Agave sisalana Perrine, oriundo do processo de extração, visando apresentar um DNA íntegro e com qualidade satisfatória, para futuros estudos de diversidade genética com marcadores moleculares para que possa servir como subsídios em futuros trabalhos de genética molecular.

\section{METODOLOGIA}

As amostras de DNA de Agave sisalana Perrine, utilizadas para a quantificação e otimização, foram oriundos da extração de DNA através do protocolo utilizando o tampão de extração. Foram realizados dois métodos de extração, com e sem a presença da epiderme da 
folha de sisal. Para ser realizado o trabalho foram coletados 15 genótipos do município de Valente, sendo utilizados estes na extração de DNA.

\section{Protocolo: Extração de DNA total por meio de maceração do tecido foliar diretamente em solução tampão de extração}

Foram macerados 0,3 gramas de tecido vegetal com $3 \mathrm{ml}$ de tampão de extração (CTAB 10\%; NaCl 5M; Tris-HCl 1M pH 8,0; EDTA 0,5M; Na Sulfite, PVP (Polivinilpirrolidona) e água mili-Q - mantido a $65^{\circ} \mathrm{C}$ ) em um saco plástico. Foram transferidos $2 \mathrm{ml}$ do macerado para tubos de $2 \mathrm{ml}$, sendo misturados por inversão e incubados por 30 minutos em banho-maria a $65^{\circ} \mathrm{C}$, agitando a cada 10 minutos. Ao atingir o tempo, centrifugou-se os tubos a $10000 \mathrm{RPM}$ a temperatura ambiente por 5 minutos, e o sobrenadante foi coletado para novos tubos de $2 \mathrm{ml}$. Foram adicionados $800 \mu \mathrm{L}$ de álcool Isoamilico e misturado por inversão. Centrifugou-se por 10 minutos a 10000 RPM a temperatura ambiente. Após coletado o sobrenadante usando ponteiras, estes foram transferidos para novos tubos de $1,5 \mathrm{ml}$. Foram adicionados $600 \mu \mathrm{L}$ de álcool Isopropilico (gelado), equivalente a aproximadamente a $2 / 3$ do volume coletado, sendo homogeneizado suavemente e incubado a $-20^{\circ} \mathrm{C}$ por 30 minutos. Foram centrifugados a 10000 $\mathrm{RPM} \mathrm{a} 4^{\circ} \mathrm{C}$ por 10 minutos e o precipitado foi lavado com $500 \mu \mathrm{L}$ de etanol $70 \%$ e foi deixado o pellet secar. O DNA isolado foi ressuspendido em $30 \mu \mathrm{L}$ de tampão TE (Tris-HCl $10 \mathrm{mM} \mathrm{pH}$ 8.0 e EDTA $1 \mathrm{mM}$ ), (RNAse $-1 \mu \mathrm{L}$ amostra) e as amostras foram colocadas na estufa a $37^{\circ} \mathrm{C}$ para a completa solubilização de DNA por 30 minutos. O DNA concentrado foi conservado a $20^{\circ} \mathrm{C}$.

Após a extração do material genético, foi realizada a diluição do DNA com o uso de TE gelado. Em seguida, foi realizada a verificação da qualidade e quantidade do DNA através de eletroforese em gel de agarose a 0,8\%. As amostras foram coradas com GelRed, e a eletroforeses a uma voltagem igual a $60 \mathrm{~W}$ por 1 hora. As amostras foram visualizadas através do sistema de fotodocumentação. A quantificação do DNA foi realizada por comparação com o DNA Fago lambda de concentração conhecida. Após quantificação, as amostras tiveram a sua concentração ajustada para $5 \mathrm{ng} / \mu \mathrm{L}$ por diluição em tampão TE e verificada, novamente, por eletroforese em gel de agarose a $1 \%$ sob as condições especificadas acima.

\section{RESULTADOS E DISCUSSÃO}

Foram realizados alguns testes para obter o melhor material para extração de DNA de sisal (Figura 1), utilizando o protocolo com aplicação do tampão de extração, variando a composição da amostra de sisal: com epiderme (região dura da casca) e sem epiderme. As amostras sem epiderme apresentaram uma maior qualidade e quantidade de DNA extraídos.

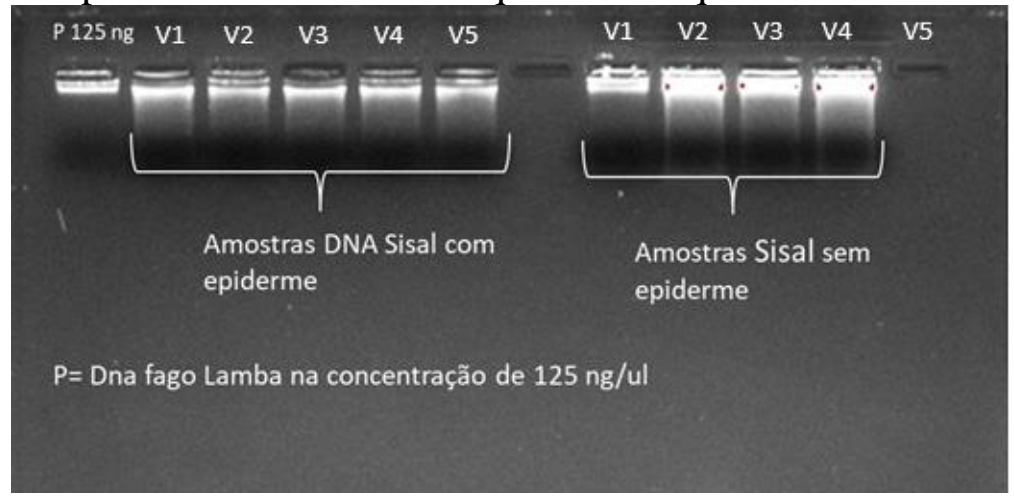

Figura 1. Teste de extração de DNA de Sisal com e sem epiderme.

No presente trabalho, o isolamento de DNA com a qualidade necessária só foi possível após a remoção da epiderme da folha do sisal. A folha tem composição carnosa, com número 
reduzido de estômatos e composta por uma cutícula cerosa, que repele a água facilmente, dificultando a ação do tampão de extração (Silva et al., 2008), sendo necessário uma maior força física durante os procedimentos do protocolo de extração. Para esse processo é recomendado a utilização de nitrogênio líquido para se obter melhor maceração da folha e DNA em quantidades satisfatórias. Dalbosco et al. (2015) em trabalhos com Orquidaceae, realizando a maceração com nitrogênio líquido, apresentou uma boa qualidade de banda na amostra.

$\mathrm{Na}$ extração, com a presença de epiderme, foi obtido um pellet após a finalização da extração com aparência degradada, o que dificultou manuseá-lo sem que se perdesse ou se degradasse completamente, gerando um grande arrasto de DNA. Entretanto, não foi verificado quando se utilizou apenas a parte carnosa da folha, um sinal claro de degradação do DNA (Figura 2). Isso se deve a liberação de compostos presentes na epiderme deixando o DNA impuro, além do maior tempo de maceração em comparação a extração sem epiderme. A integridade do DNA é fundamental para a clareza e reprodutibilidade dos produtos de amplificação pela PCR (Ferreira; Grattapaglia, 1998).

No processo de extração sem epiderme foi verificada baixa concentração de polissacarídeos nas amostras, pois as bandas não apresentaram forma cônica em direção ao polo positivo ou muito DNA retido no poço do gel. Além disso, verificou-se que todas as amostras estavam livres de RNA (Figura 3), pois não foram observadas bandas com menor massa molecular no gel (Chiari, 2009).

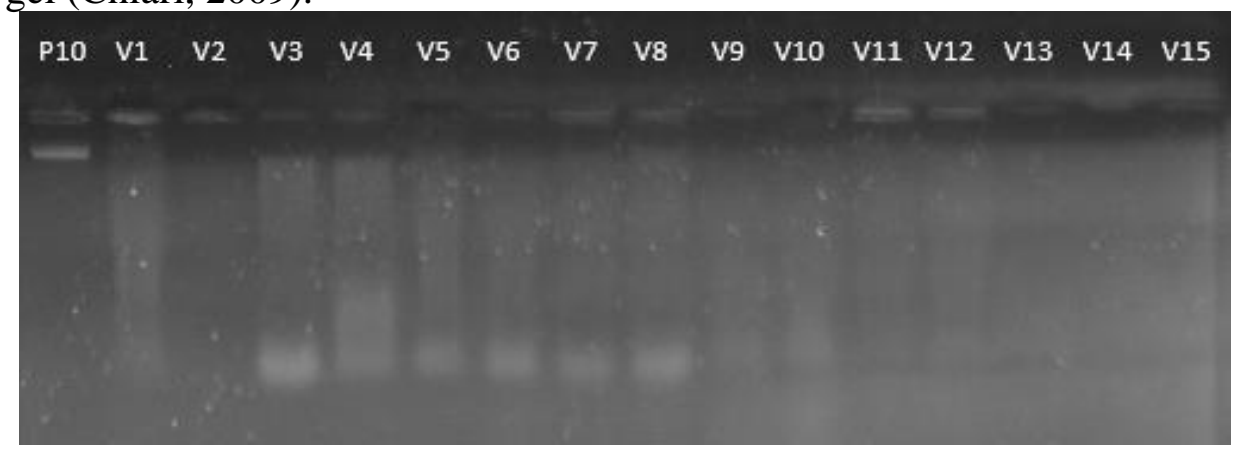

Figura 2. Quantificação e otimização de DNA genômico de sisal utilizando o protocolo de extração de DNA total por meio de maceração do tecido foliar diretamente em solução tampão de extração. Amostras aplicadas com volume de $6 \mu \mathrm{L}$. Amostra P10) $\lambda 10$ ng, V1 a V15) amostras coletadas no município de Valente, BA.

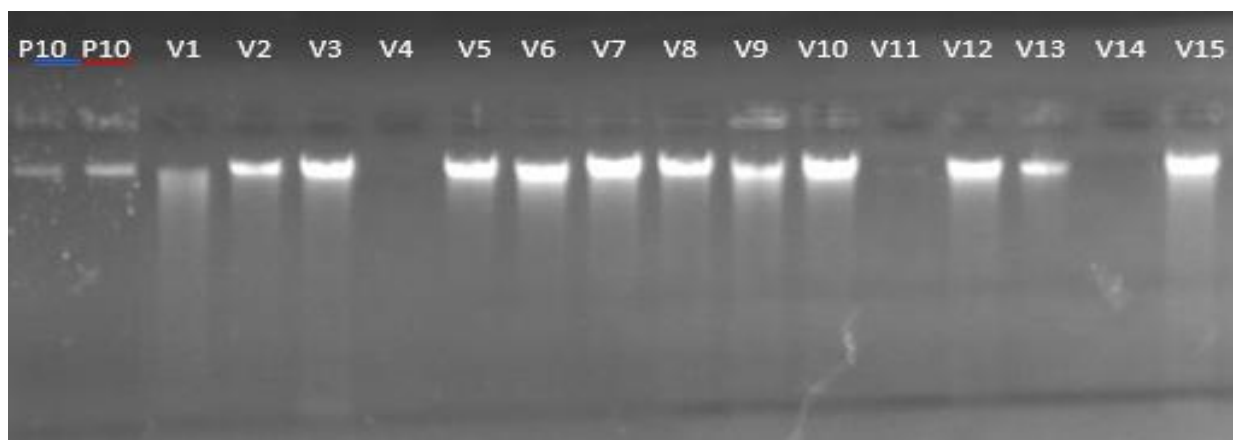

Figura 3. Quantificação e otimização de DNA genômico de sisal utilizando o protocolo de extração de DNA total por meio de maceração do tecido foliar diretamente em solução tampão de extração. Amostras aplicadas com volume de $6 \mu \mathrm{L}$. Amostra P10) $\lambda 10$ ng, P10) $\lambda 10 \mathrm{ng}, \mathrm{V} 1$ a V15) amostras coletadas no município de Valente, BA.

Após otimização do protocolo, o mesmo será utilizado nas extrações de rotina no LAGEM, possibilitando a utilização do DNA extraído em estudos moleculares para a cultura do sisal (Figura 4). 


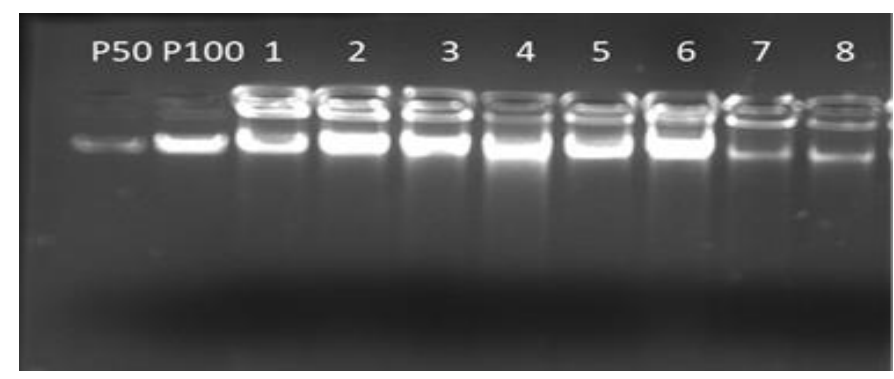

Figura 4. Extração de DNA de Sisal sem epiderme utilizando o protocolo otimizado.

\section{CONCLUSÕES}

Para o protocolo testado o uso da folha de sisal sem a epiderme foi o mais adequado para extração de DNA para a obtenção de material genético em quantidade e qualidade necessárias.

Para a extração de DNA a partir da folha com a epiderme é recomendável a maceração na presença de nitrogênio líquido, propiciando a redução de força e física e presença de compostos indesejados.

\section{REFERÊNCIAS}

AQUINO, D. F. 2011. Sisal - Proposta de Preço Mínimo 2012/2013: Conab, 2012 - Estudos Internos.

BUTLER, J. M. 2010. Fundamentals of Forensic DNA Typing. Academic Press.

CARDONA, J. O. 2010. Análisis de diversidad genética de las razas colombianas de maíz a partir de datos Roberts et al., (1957) usando la estratégia Ward-WLM. Ciência e Agrotecnologia, Lavras, v. 2, n.1, p. 199-207.

CHIARI, L. 2009. Comparação de três métodos de extração de DNA genômico para análises moleculares em Stylosanthes guianensis. Circular Técnica - Embrapa. Campo Grande, MS.

DALBOSCO, E. Z. SILVA, C. G. MELHORANÇA, E. A. L. MIRANDA, A. F. SILVA, C. A. 2015. OTIMIZAÇÃO DO PROTOCOLO PARA EXTRAÇÃO DE DNA GENÔMICO DE Epidendrum viviparum Lindl. (Orchidaceae). ENCICLOPÉDIA BIOSFERA, Centro Científico Conhecer - Goiânia, v.11 n.21; p. 3236.

FERREIRA, M. A. J. F. 2003. Utilização das técnicas de marcadores moleculares na genética de populações, na genética quantitativa e no melhoramento de plantas. Boa Vista: Embrapa Roraima (Embrapa Roraima. Documentos, 1). 63p.

FERREIRA, M. E.; GRATTAPAGLIA, D. 1998. Introdução ao uso de marcadores moleculares em análise genética. 3. ed. Brasília, DF: Embrapa Recursos Genéticos e Biotecnologia, 220 p. il. (Embrapa Recursos Genéticos e Biotecnologia. Documentos, 20).

ROMANO, E. 1998. EXTRAÇÃO DE DNA DE TECIDOS VEGETAIS. In: BRASILEIRO, A. C. M.; CARNEIRO, V. T. C. (Ed). Manual de transformação genética de plantas. Brasília. EMBRAPA-SPI/EMBRAPA-CENARGEN. p.163-177.

SANTOS, C.A.F.; OLIVEIRA, V.R.; KIILL, L.H.P.; SÁ, I.I.S. 2007. Variabilidade genética, com base em marcadores RAPD, de três espécies arbóreas ameaçadas de extinção no Semi-Árido brasileiro. Scientia Forestalis, v.74, p.37-44.

SILVA, O. R. R. F. COUTINHO, W. M. CARTAXO, W. V. SOFIATTI, V. FILHO, J. L. S. CARVAlHO, O. S. COSTA, L. B. 2008. Cultivo do Sisal no Nordeste Brasileiro. Ministério da Agricultura, Pecuária de Abastecimento. Campina Grande, PB.

TIWARI K. S. et al. 2005. MODIFIED CTAB TECHINIQUE FOR ISOLATION OF DNA FROM SOME MEDICINAL PLANTS. Journal of Medicinal Plant, v.6, p.65. 2012. BENNETT, M. D. LEITCH, I. J. Plant genome size research: A field in focus. Ann. Bot. 95: $1-6$. 